\title{
Lipid changes in boar spermatozoa during epididymal maturation with some observations on the flow and composition of boar rete testis fluid
}

\author{
R. W. Evans* and B. P. Setchell \\ A.R.C. Institute of Animal Physiology, Babraham, Cambridge CB2 4AT, U.K.
}

\begin{abstract}
Summary. The flow rate and composition of boar rete testis fluid were similar to those in other species studied previously. The total phospholipid phosphorus and phospholipid fatty acid content of boar spermatozoa decreased during maturation in the epididymis but the level of phospholipid phosphorus was slightly higher in ejaculated spermatozoa than in epididymal spermatozoa. During passage of the spermatozoa from the testis to the cauda epididymidis, loss of the major saturated acids (palmitic, 16:0, and stearic, 18:0) was extensive but partly recovered in the ejaculated spermatozoa. The mass of docosapentaenoic $(22: 5)$ and docosahexaenoic (22:6) acids tended to decrease continuously during maturation but the percentage of $22: 6$ by weight of total phospholipid fatty acid reached a maximum in the epididymis.

Ejaculated boar spermatozoa contained considerably more phospholipid and phospholipid fatty acid than did ejaculated bull or ram spermatozoa.
\end{abstract}

\section{Introduction}

Spermatozoa acquire their fertilizing ability during their passage through the epididymis. During this time, they undergo a number of biochemical, morphological and physiological changes but the relationship between these and the attainment of fertilizing ability is not understood (see Bedford, 1975; Orgebin-Crist, Danzo \& Davies, 1975).

The substrate metabolized by spermatozoa during their long sojourn in the epididymis also remains unknown. Scott, Voglmayr \& Setchell (1967) observed that in ram spermatozoa the mass of all phospholipids except choline plasmalogen decreased during maturation and suggested that spermatozoa utilized the fatty acid side chains of their phospholipids as energy sources. Similar phospholipid changes were reported by Poulos, Brown-Woodman, White \& Cox (1975) for ram spermatozoa and by Poulos, Voglmayr \& White (1973a) for bull spermatozoa although Poulos et al. (1975) also noted some loss of choline plasmalogen. Dacheux (1977) reported that the total phospholipid content of rat and ram spermatozoa decreased during maturation. Other data available in the literature are conflicting. Dawson \& Scott (1964) noted that the phospholipid content of rat spermatozoa appeared to increase, as a result of a large increase in their choline plasmalogen content, during their passage through the epididymis.

Loss of phospholipid during maturation may explain the greater sensitivity of ejaculated spermatozoa than testicular spermatozoa to cold shock (Scott et al., 1967). Boar spermatozoa are much more susceptible to damage during freezing than bull or ram spermatozoa, but apart from the studies by Grogan, Mayer \& Sikes (1966) and Johnson, Pursel \& Gerrits (1972) on spermatozoa obtained by crude techniques from three regions of the epididymides of dead animals, there have been no investigations on the lipid composition of maturing boar

\footnotetext{
* Present address: Department of Biochemistry, University of Ottawa, Canada.
} 
spermatozoa or on the proportions of various fatty acids in their phospholipids and neutral lipids. We have therefore studied the phospholipid and neutral lipid composition of uncontaminated samples of boar spermatozoa, collected by cannulating the rete testis and ductus deferens, and compared these with ejaculated spermatozoa of the boar and other species.

\section{Materials and Methods}

\section{Collection and treatment of spermatozoa}

Continuous collections of testicular fluid were made from 6 Large White boars, aged between 14 and 51 months and weighing between 200 and $270 \mathrm{~kg}$, by the technique of Voglmayr, Scott, Setchell \& Waites (1967) as modified by Suominen and Setchell (1972) and Evans \& Setchell (1978a). Each sample was examined for microbial contamination by staining an air-dried smear with Gram stain and examining it with an oil immersion objective. The sample was discarded if two or more bacteria were present per 100 spermatozoa.

Samples of epididymal semen were collected as described by Evans \& Setchell (1978a). Boar semen was obtained by manual collection using a dummy sow. The semen was strained through cheesecloth to remove gel. Bull and ram semen was obtained by collection into an artificial vagina.

Before counting in a haemocytometer, boar epididymal and bull ejaculated samples were diluted 1 to 200 and boar testicular and ejaculated samples 1 to 20 with saline $(9 \mathrm{~g} \mathrm{NaCl} / \mathrm{l})$.

Spermatozoa were separated from the fluid in which they were collected by the techniques described by Evans \& Setchell (1978a). The supernatants were removed immediately and the spermatozoa were extracted. To remove any spermatozoa remaining in the supernatants they were drawn under vacuum through filter paper (Carlson-Ford filter sheets, HP/EKS: Carlson Ford, Ltd, Ashton-under-Lyme, Lancs) before lipid extraction. Blood samples were collected from a catheter in a marginal ear vein.

\section{Analytical techniques}

Spermatozoa and fluid samples were extracted, phospholipids and neutral lipids separated and the phospholipids analysed as described by Evans \& Setchell (1978a, b). Neutral lipids were saponified using $6 \%$ potassium hydroxide in $95 \%$ ethanol in water $(\mathrm{v} / \mathrm{v})$ (Wilde \& Dawson, 1966); the fatty acids obtained were methylated with diazomethane in methanol-ether $(1: 9, \mathrm{v} / \mathrm{v})$ (Schlenk \& Gellerman, 1960) and the esters were separated by gas-liquid chromatography as described by Evans \& Setchell (1978b). Identification of the peaks after gas-liquid chromatography was by comparison with standards and with values for retention time reported in the literature (Burchfield \& Storrs, 1962). The fatty acid notation used is that of Ahrens et al. (1959).

Rete testis fluid was analysed for sodium and potassium by flame photometry, chloride by coulometric titration, glucose with a glucose oxidase reagent (GOD-perid: Boehringer, Lewes, Sussex, U.K.), total protein by the technique of Hartree (1972), inositol by the technique of Hinton, Setchell \& White (1977) and amino acids with a Locarte amino acid analyser on proteinfree filtrates prepared by mixing the fluid or plasma with an equal volume of $10 \%(\mathrm{w} / \mathrm{v})$ sulphosalicyclic acid and centrifuging ( $10000 \mathrm{~g}$ for $20 \mathrm{~min})$.

\section{Results}

Fluid flowed from the rete testis catheters in 10 testes weighing between 356 and $665 \mathrm{~g}(530 \pm$ 33 s.e.m. g) of 6 animals at a rate of $2.8 \pm 0.29 \mathrm{ml} / \mathrm{hr}$ (31 observations made over periods from 1 to $16 \mathrm{~h}$ ). The catheters remained patent only for between several hours and 3 days, as they were easily dislodged by the animal when conscious. 
The concentration of spermatozoa was $91 \times 10^{6} \pm 8.9 \times 10^{6} / \mathrm{ml}(n=31)$. As shown in Table 1 there was more potassium, chloride and inositol in rete testis fluid and less sodium, glucose and protein than in blood plasma. Some amino acids were present in higher concentrations in rete testis fluid than in blood plasma, some were present in similar concentrations but most were present in lower concentrations.

Table 1. The composition (mean \pm s.e.m.) of rete testis fluid from 3 or 6 boars, compared with blood plasma from the same animals

\begin{tabular}{|c|c|c|c|c|c|}
\hline \multirow{2}{*}{$\begin{array}{l}\text { Substance } \\
\text { Sodium (mM) } \\
\text { Potassium (mM) } \\
\text { Chloride (mM) }\end{array}$} & \multirow{2}{*}{$\begin{array}{c}\text { No. of samples } \\
6 \\
6 \\
6\end{array}$} & \multicolumn{2}{|c|}{ Rete testis fluid } & \multicolumn{2}{|c|}{ Blood plasma } \\
\hline & & $\begin{array}{l}116 \\
8 \cdot 8 \\
137\end{array}$ & $\begin{array}{l} \pm 4.5 \\
\pm 0.9 \\
\pm 1.8\end{array}$ & $\begin{array}{c}139 \\
6 \cdot 1 \\
90\end{array}$ & $\begin{array}{l} \pm 3.7 \\
\pm 0.33 \\
\pm 2.4\end{array}$ \\
\hline $\begin{array}{l}\text { Glucose }(\mathrm{mm}) \\
\text { Inositol }(\mathrm{mM}) \\
\text { Total protein }(\mathrm{mg} / \mathrm{ml})\end{array}$ & $\begin{array}{l}6 \\
6 \\
6\end{array}$ & $\begin{array}{r}<0 \cdot 1 \\
5 \cdot 8 \\
1 \cdot 1\end{array}$ & $\begin{array}{l} \pm 0.18 \\
\pm 0.12\end{array}$ & $\begin{array}{l}4.4 \\
0.04 \\
65\end{array}$ & $\begin{array}{l} \pm 0.78 \\
\pm 0.01 \\
\pm 5.3\end{array}$ \\
\hline $\begin{array}{l}\text { Aspartic acid (mM) } \\
\text { Glutamic acid (mM) } \\
\text { Glycine (mM) }\end{array}$ & $\begin{array}{l}3 \\
3 \\
3\end{array}$ & $\begin{array}{l}0.22 \\
1 \cdot 92 \\
1 \cdot 23\end{array}$ & $\begin{array}{l} \pm 0.047 \\
\pm 0.061 \\
\pm 0.086\end{array}$ & $\begin{array}{l}0.06 \\
0.26 \\
0.85\end{array}$ & $\begin{array}{l} \pm 0.029 \\
\pm 0.22 \\
\pm 0.24\end{array}$ \\
\hline $\begin{array}{l}\text { Threonine (mM) } \\
\text { Serine (mM) } \\
\text { Glutamine (mM) } \\
\text { Alanine (mM) }\end{array}$ & $\begin{array}{l}3 \\
3 \\
3 \\
3\end{array}$ & $\begin{array}{l}0.16 \\
0.17 \\
0.54 \\
0.58\end{array}$ & $\begin{array}{l} \pm 0.033 \\
\pm 0.070 \\
\pm 0.032 \\
\pm 0.050\end{array}$ & $\begin{array}{l}0.17 \\
0.13 \\
0.55 \\
0.52\end{array}$ & $\begin{array}{l} \pm 0.022 \\
\pm 0.050 \\
\pm 0.19 \\
\pm 0.16\end{array}$ \\
\hline $\begin{array}{l}\text { Taurine (mM) } \\
\text { Proline (mM) } \\
\text { Citrulline (mM) } \\
\text { Valine (mM) } \\
\text { Methionine (mM) } \\
\text { iso Leucine (mM) } \\
\text { Leucine (mM) } \\
\text { Tyrosine (mM) } \\
\text { Phenylalanine (mM) } \\
\text { Histidine (mM) } \\
\text { Ornithine (mM) } \\
\text { Lysine (mM) } \\
\text { Arginine (mM) }\end{array}$ & $\begin{array}{l}3 \\
3 \\
3 \\
3 \\
3 \\
3 \\
3 \\
3 \\
3 \\
3 \\
3 \\
3 \\
3\end{array}$ & $\begin{array}{r}0.00 \\
0.00 \\
\text { Not d } \\
0.07 \\
0.01 \\
0.04 \\
0.05 \\
0.01 \\
0.01 \\
0.02 \\
0.01 \\
0.05 \\
0.04\end{array}$ & $\begin{array}{l} \pm 0.005 \\
\pm 0.002 \\
\text { tectable } \\
\pm 0.016 \\
\pm 0.007 \\
\pm 0.007 \\
\pm 0.006 \\
\pm 0.003 \\
\pm 0.003 \\
\pm 0.007 \\
\pm 0.004 \\
\pm 0.011 \\
\pm 0.004\end{array}$ & $\begin{array}{l}0.09 \\
0.26 \\
0.09 \\
0.45 \\
0.05 \\
0.28 \\
0.33 \\
0.07 \\
0.09 \\
0.06 \\
0.12 \\
0.13 \\
0.14\end{array}$ & $\begin{array}{l} \pm \pm 0.012 \\
\pm 0.022 \\
\pm 0.012 \\
\pm 0.094 \\
\pm 0.007 \\
\pm 0.033 \\
\pm 0.037 \\
\pm 0.003 \\
\pm 0.014 \\
\pm 0.017 \\
\pm 0.024 \\
\pm 0.042 \\
\pm 0.015\end{array}$ \\
\hline
\end{tabular}

The phospholipid phosphorus content of boar spermatozoa decreased significantly $(P<$ $0.001)$ during maturation from $22.7 \pm 2.2(n=11) \mu \mathrm{g} \mathrm{P} / 10^{8}$ testicular spermatozoa (multiply by 25 to obtain value for phospholipid) to $11.32 \pm 1.0(n=9) \mu \mathrm{g} \mathrm{P} / 10^{8}$ epididymal spermatozoa. Ejaculated spermatozoa contained only slightly more phospholipid phosphorus (13.9 and $14.7 \mu \mathrm{g} \mathrm{P} / 10^{8}$ spermatozoa, 2 samples) than epididymal spermatozoa. Boar ejaculated spermatozoa also contained considerably more phospholipid phosphorus than did bull $\left(7.80 \pm 0.92 \mu \mathrm{g} \mathrm{P} / 10^{8}\right.$ spermatozoa, $\left.n=8 ; P<0.01\right)$ or $\mathrm{ram}\left(9.00\right.$ and $9.04 \mu \mathrm{g} \mathrm{P} / 10^{8}$ spermatozoa, $n=2 ; P<0.01)$ ejaculated spermatozoa.

A similar decrease for the total phospholipid fatty acid content of boar spermatozoa was noted during maturation although the values for epididymal and ejaculated spermatozoa were similar (Table 2).

Qualitatively, the distribution of acids in the phospholipids of testicular and ejaculated spermatozoa was similar but the unsaturation level of the epididymal acids was greatly increased. The percentage by weight of palmitic $(16: 0)$ and stearic $(18: 0)$, the major saturated components, decreased during maturation and rose at ejaculation whereas that of $22: 6$, the main unsaturated acid, increased during maturation and then fell at ejaculation. All other acids showed no change or decreased during maturation except for a minor component, myristic acid (14:0), which increased (Table 2). The overall effect of these changes was that the mass of most 
individual acids, except myristic $(14: 0)$, decreased during maturation but the extent varied with the individual acid. Palmitic $(16: 0)$ and stearic $(18: 0)$, decreased to very low levels in the epididymis but partly recovered during ejaculation. Oleic $(18: 1)$ and linoleic $(18: 2)$ acids showed a similar pattern although the changes were smaller. The masses of the main unsaturated acids $22: 5$ and 22:6, decreased throughout maturation and ejaculation and ejaculated spermatozoa contained about half as much of these acids as testicular spermatozoa.

Table 2. Composition of the fatty acids of the phospholipids of boar and bull spermatozoa

\begin{tabular}{|c|c|c|c|c|c|c|c|}
\hline & \multicolumn{5}{|c|}{ Boar spermatozoa } & \multirow{2}{*}{\multicolumn{2}{|c|}{$\frac{\text { Bull spermatozoa }}{\text { Ejaculated }}$}} \\
\hline & Testicular & & Epididymal & & Ejaculated & & \\
\hline No. of samples & 4 & & 2 & & 3 & & 8 \\
\hline No. of animals & 2 & & 2 & & 2 & & 3 \\
\hline $\begin{array}{l}\text { Total fatty acid } \\
\left(\mu \mathrm{g} / 10^{8} \text { spermatozoa }\right)\end{array}$ & $284 \cdot 7 \pm 26 \cdot 2$ & $*$ & 127,145 & & $136.4 \pm 2.9$ & $* * *$ & $50 \cdot 5 \pm 8 \cdot 3$ \\
\hline \multicolumn{8}{|l|}{$\begin{array}{l}\text { Individual fatty acids } \\
\text { (as } \% \text { of total) }\end{array}$} \\
\hline $14: 0$ & $0.1 \pm 0.1$ & * & $0.6,0.6$ & & $1 \cdot 6 \pm 0.5$ & & $1 \cdot 0 \pm 0.5$ \\
\hline $16: 0$ & $17.2 \pm 3.0$ & * & $3.4,3.6$ & * & $12.8 \pm 1.2$ & & $13.3 \pm 1.4$ \\
\hline $18: 0$ & $7.7 \pm 0.9$ & ** & $1.6,1.8$ & ** & $6.2 \pm 0.4$ & & $6 \cdot 1 \pm 1 \cdot 0$ \\
\hline $18: 1$ & $1.5 \pm 0.2$ & $* *$ & $0.6, \quad 0.8$ & & $2.8 \pm 0.6$ & & $3.2 \pm 0.2$ \\
\hline $18: 2$ & $1.9 \pm 0.1$ & **** & $0.8,0.8$ & & $1.8 \pm 0.2$ & **** & $4.2 \pm 0.7$ \\
\hline $18: 3$ & Trace & & Trace & & $0.1 \pm 0.1$ & & $0.6 \pm 0.6$ \\
\hline $20: 2$ & $0.2 \pm 0.1$ & & Trace & & $0.5 \pm 0.3$ & & $1.2 \pm 0.8$ \\
\hline $20: 3$ & $3.5 \pm 0.4$ & ** & $1.0,1.4$ & & $1.7 \pm 0.4$ & & $2.6 \pm 1.6$ \\
\hline $20: 4$ & $4.5 \pm 0.5$ & & $2 \cdot 9,3 \cdot 1$ & & $3.7 \pm 1.3$ & & $5.3 \pm 0.7$ \\
\hline $20: 5$ & $1.1 \pm 0.4$ & & $1 \cdot 8,0$ & & $1.1 \pm 0.6$ & & $1.0 \pm 0.7$ \\
\hline $22: 5$ & $24.2 \pm 1.5$ & & $30 \cdot 7,29 \cdot 9$ & & $24 \cdot 3 \pm 2 \cdot 0$ & *** & $3.2 \pm 0.8$ \\
\hline $22: 6$ & $38 \cdot 1 \pm 3 \cdot 3$ & ** & $56 \cdot 8,58 \cdot 4$ & * & $43.4 \pm 2.2$ & $*$ & $58 \cdot 2 \pm 3 \cdot 3$ \\
\hline
\end{tabular}
( $t$ test).

Values in adjacent columns which are significantly different are indicated: ${ }^{*} P<0.05 ;{ }^{* *} P<0.01 ;{ }^{* * *} P<0.001$

Table 3. Composition of the fatty acids of 2 samples of rete testis fluid and seminal plasma from different boars

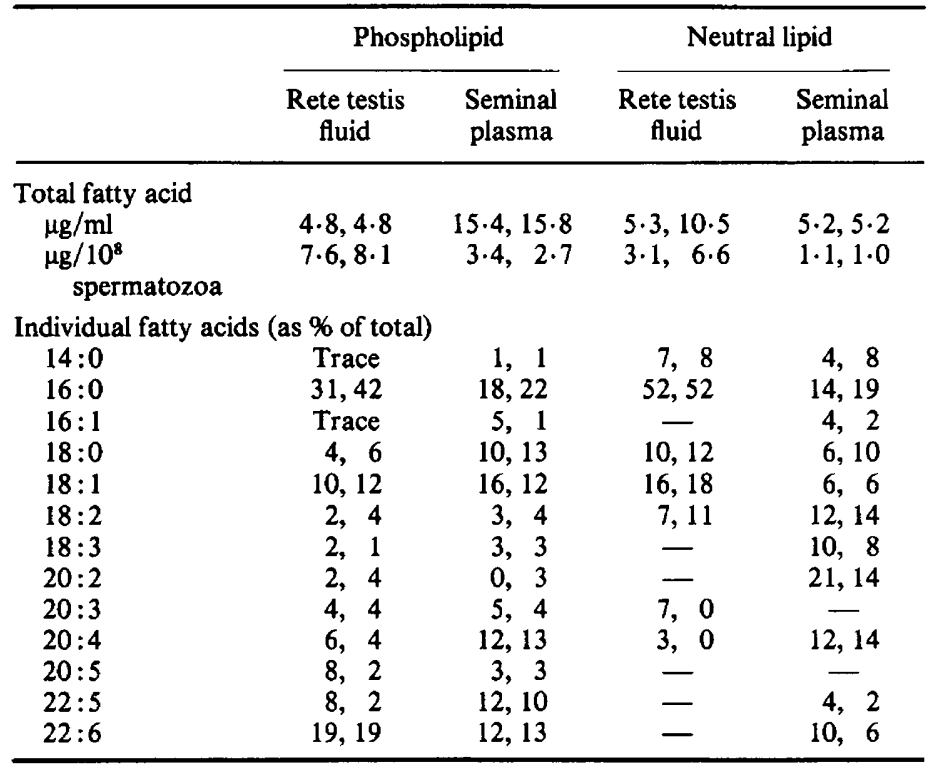


The fatty acid composition of lipids from rete testis fluid and seminal plasma is presented in Table 3. The mass of phospholipid and neutral lipid fatty acid in both fluids was low. Palmitic acid $(16: 0)$ was the major component of the phospholipids in boar testicular fluid but $22: 6$ and oleic acid $(18: 1)$ were also present in appreciable amounts. In seminal plasma 6 acids, 16:0, $18: 0,18: 1,20: 4,22: 5$ and $22: 6$, present in similar amounts, accounted for over $80 \%$ of the total phospholipid fatty acids. The fatty acids of the neutral lipids in rete testis fluid were mainly palmitic, and, in seminal plasma, the fatty acids $16: 0,18: 2,18: 3,20: 2$ and $20: 4$, in approximately equal proportions, made up about $70 \%$ of the total with smaller amounts of $14: 0$, $16: 1,18: 0,18: 1,22: 5$ and $22: 6$.

Bull ejaculated spermatozoa contained considerably less phospholipid fatty acid than boar ejaculated spermatozoa but the unsaturation level of their acids was similar (Table 2). Bull spermatozoa, however, contained very little $22: 5$ although it was a major component of boar spermatozoa.

The neutral lipid content of boar spermatozoa did not show any significant changes during epididymal maturation or ejaculation. The fatty acids of the neutral lipids were mainly $16: 0$ and 18:0 in the testicular samples and 14:0,16:0 and 18:0 in the epididymal and ejaculated samples; the percentage of 14:0 increased during maturation, while those of 16:0 and 18:0 decreased. There were no further qualitative changes at ejaculation (Table 4).

Table 4. Composition of the fatty acids of the neutral lipids from boar spermatozoa

\begin{tabular}{|c|c|c|c|c|}
\hline & \multicolumn{4}{|c|}{ Spermatozoa } \\
\hline & Testicular & & Epididymal & Ejaculated \\
\hline No. of samples & 4 & & 2 & 2 \\
\hline No. of animals & 2 & & 2 & 2 \\
\hline \multicolumn{5}{|l|}{ Total fatty acid } \\
\hline \multicolumn{5}{|l|}{$\begin{array}{l}\text { Individual fatty acids } \\
\text { (as \% of total) }\end{array}$} \\
\hline $14: 0$ & $4.0 \pm 0.6$ & $* * *$ & $37 \cdot 5,38 \cdot 5$ & $33 \cdot 1,38 \cdot 1$ \\
\hline $16: 0$ & $51 \cdot 1 \pm 3.4$ & * & $35 \cdot 5,33 \cdot 5$ & $34 \cdot 3,34 \cdot 3$ \\
\hline $18: 0$ & $24.6 \pm 1.7$ & * & $14 \cdot 5,15 \cdot 5$ & $18 \cdot 6,16 \cdot 6$ \\
\hline $18: 1$ & $8.1 \pm 0.3$ & & $6 \cdot 1,5 \cdot 7$ & $7 \cdot 5, \quad 7 \cdot 3$ \\
\hline $18: 2$ & $2.4 \pm 0.4$ & & $1 \cdot 7,2 \cdot 5$ & $1 \cdot 7, \quad 1.3$ \\
\hline $20: 2$ & $0.8 \pm 0.4$ & & $0, \quad 0$ & $0, \quad 0.2$ \\
\hline $20: 3$ & $2.6 \pm 1.0$ & & $0, \quad 0$ & $0, \quad 1.8$ \\
\hline $20: 4$ & $1.8 \pm 0.3$ & & $2 \cdot 9, \quad 2.9$ & $2.4,0.4$ \\
\hline $22: 5$ & $1.2 \pm 1.2$ & & $0, \quad 0$ & $2 \cdot 2, \quad 0$ \\
\hline $22: 6$ & $2.6 \pm 0.8$ & & $2 \cdot 4, \quad 1 \cdot 6$ & $0, \quad 0$ \\
\hline
\end{tabular}

Values in adjacent columns which are significantly different are indicated: ${ }^{*} P<0.05 ;{ }^{* * *} P<0.001$.

\section{Discussion}

The flow and composition of rete testis fluid in the boar seems essentially similar to that in other species studied (See Setchell, 1978). The value reported here for the phospholipid content (calculated from the phosphorus content) of ejaculated boar spermatozoa $\left(358 \mu \mathrm{g} / 10^{8}\right.$ spermatozoa) is higher than those observed by Johnson et al. $\left(1969,1972 ; 180\right.$ and $200 \mu \mathrm{g} / 10^{8}$ spermatozoa respectively). Similarly, the figure for bull ejaculated spermatozoa $\left(195 \mu \mathrm{g} / 10^{8}\right.$ spermatozoa) is higher than those reported by Pursel \& Graham (1967) and Clegg \& Foote (1973) (140 and $135 \mu \mathrm{g} / 10^{8}$ spermatozoa respectively) but similar to that observed by Poulos $e t$ 
al. (1973a) (220 $\mathrm{gg} / 10^{8}$ spermatozoa). The figures reported by Poulos et al. (1973a) for the approximate mass of phospholipid fatty acid in bull ejaculated spermatozoa are about twice the amount observed during this study. Possible reasons for these differences are discussed by Evans \& Setchell (1979).

Qualitatively, the results for the phospholipid fatty acids are in close agreement with those appearing in the literature (Neill \& Masters, 1972; Poulos et al., 1973a; Poulos, Darin-Bennett \& White, 1973b). Johnson et al. (1972), however, observed a greater content of docosapentaenoic $(22: 5)$ acid in epididymal and ejaculated boar spermatozoa and much more paimitic in epididymal boar spermatozoa. An increase in the unsaturation of the phospholipid fatty acids of boar spermatozoa during passage through the epididymis is similar to the response exhibited by bovine spermatozoa (Poulos et al., 1973a) and by ram spermatozoa (Poulos et al., 1975; Evans \& Setchell, 1979) but is even more extreme. Only $6 \%$ of the phospholipid fatty acids of boar epididymal spermatozoa were saturated; in contrast to this, about $90 \%$ of the fatty acids of the neutral lipids were saturated.

The nature of its fatty acyl groups greatly affect the physicochemical properties of a phospholipid (de Gier, Mandersloot \& Van Deenen, 1968; Moore, Richardson \& DeLuca, 1969; Baldassare, Rhinehart \& Silbert, 1976). The rate of turnover of phospholipids and their ability to restore activity to lipid-depleted mitochondria can be altered by differences in unsaturation (Collins, 1960; Jurtschuk, Sekuzu \& Green, 1961; Trewhella \& Collins, 1969). The characteristics of growth, respiration and galactoside transport in bacteria are related to the nature of the bacterial phospholipid fatty acids (Overath, Schairer \& Stoffel, 1970). In addition, an inverse relationship between the degree of unsaturation of lipids and growth temperature has been demonstrated in a wide variety of organisms: fish (Lewis, 1962); bacteria (Marr \& Ingraham, 1962); fungi (Pearson \& Raper, 1927); plants (Howell \& Collins, 1957); and insects (Fraenkel \& Hopf, 1940). In particular, it has been reported (Davis \& Silbert, 1974) that when the saturated fatty acid content of the membrane lipid of $E$. coli mutants is reduced below $15 \%$ then the permeability of the membrane towards $\mathrm{K}^{+}$and a lactose analogue is greatly increased. The qualitative changes observed in boar spermatozoa during maturation will, therefore, be expected to modify the properties of the sperm membrane.

It would be surprising if the changes were exclusively the result of the spermatozoa utilizing their phospholipid acyl groups as energy sources, as in these circumstances the spermatozoa would have been expected to maintain their particular fatty acid composition; incubation of ram testicular spermatozoa in vitro resulted in loss of phospholipid fatty acid but no change in the percentage composition of the acids was observed (Evans \& Setchell, 1978b). The qualitative changes in vivo may therefore indicate that the spermatozoa adapt their membranes to the new environment in the epididymis. Such speculation, however, is greatly hampered by not knowing how extensively the cytoplasmic droplets participated in the phospholipid changes observed. These organelles usually completely dissociate from spermatozoa during maturation (Gresson \& Zlotnik, 1945; Branton \& Salisbury, 1947) and alterations in their lipid content need not affect the characteristics of the sperm membranes.

An increase in the phospholipid content of the boar spermatozoa during ejaculation, rather than indicating synthesis, is possibly the result of the spermatozoa taking up phospholipids present in the seminal plasma. Evans \& Setchell (1978a) have reported that exogenous phospholipid associates with boar spermatozoa to a much greater extent than with bull or ram spermatozoa, and the ejaculated spermatozoa of rams do not contain more phospholipid than do epididymal spermatozoa (Quinn \& White, 1967). Analysis of the phospholipids of boar seminal plasma showed that they do contain the fatty acids that increased in mass within the spermatozoa namely $16: 0,18: 0,18: 1$ and $18: 2$, but the levels were low in the seminal plasma. These values represent the phospholipid fatty acids remaining in the seminal plasma after removal of the spermatozoa. Johnson et al. (1972) reported that porcine seminal vesicle fluid contained considerably more phospholipid than did sperm-rich plasma (210 and $35 \mu \mathrm{g} / \mathrm{ml}$ 
respectively). In addition, the major fatty acid components of the phospholipids in seminal vesicle fluid were 18:0,18:1 and 18:2 which all increased in boar spermatozoa during ejaculation; $22: 5$ and 22:6 continued to decrease in boar spermatozoa during ejaculation and these were absent from the seminal vesicle fluid. The only exception was palmitic acid which increased in the spermatozoa but was a minor component of the seminal vesicle fluid.

The phospholipid content of ejaculated boar spermatozoa was higher than that of ejaculated bull or ram spermatozoa. Therefore the order for the phospholipid content of the ejaculated spermatozoa of these three species is the reverse of that of the increasing sensitivity of these spermatozoa to damage after freezing in protective diluents and to their fertility after low temperature storage (Darin-Bennett, Poulos \& White, 1973). A higher level of phospholipid therefore does not appear to be an advantage to spermatozoa during low temperature storage, although an analysis of the distribution of the phospholipids within the spermatozoa may prove instructive.

We are grateful to Mr P. C. Wright for the amino acid analyses and Mr B. T. Hinton for the inositol analyses. R.W.E. was in receipt of a Meat and Livestock Commission Scholarship during this work.

\section{References}

Ahrens, E.H., Insull, W., Hirsch, J., Stoffel, W., Petersen, M.L., Farquhar, J.W., Miller, T. \& Thomasson, H.J. (1959) The effect on human serum-lipids of a dietary fat, highly unsaturated, but poor in essential fatty acids. Lancet i, 115-119.

Baldassare, J.J., Rhinehart, K.B. \& Silbert, D.F. (1976) Modification of membrane lipid: physical properties in relation to fatty acid structure. Biochemistry, N.Y. 15, 2986-2994.

Bedford, J.M. (1975) Maturation, transport, and fate of spermatozoa in the epididymis. In Handbook of Physiology, Section 7, Vol. V, pp. 303-317. Eds D. W. Hamilton \& R. O. Greep. Am. Physiol. Soc., Washington, D.C.

Branton, C. \& Salisbury, G. (1947) Morphology of spermatozoa from different levels of the reproductive tract of the bull. J. Anim. Sci. 6, 154-160.

Burchfield, H.P. \& Storrs, E.E. (1962) Biochemical Applications of Gas Chromatography, pp. 549-554. Academic Press, New York.

Clegg, E.D. \& Foote, R.H. (1973) Phospholipid composition of bovine sperm fractions, seminal plasma and cytoplasmic droplets. J. Reprod. Fert. 34, 379-383.

Collins, F.D. (1960) Heterogeneity of lecithins labelled with phosphorus-32. Nature, Lond. 186, 366-367.

Dacheux, D.L. (1977) Investigation of the variation in total phospholipid content of the spermatozoa of the rat and the ram during epididymal transport. IRCS Medical Science 5, 18.

Darin-Bennett, A., Poulos, A. \& White, I.G. (1973) The effect of cold shock and freeze-thawing on release of phospholipids by ram, bull and boar spermatozoa. Aust. J. biol. Sci. 26, 1409-1420.

Davis, M.-T.B. \& Silbert, D.F. (1974) Changes in cell permeability following a marked reduction of saturated fatty acid content of Escherichia Coli K12. Biochim. Biophys. Acta 373, 224-241.
Dawson, R.M.C. \& Scott, T.W. (1964) Phospholipid composition of epididymal spermatozoa prepared by density gradient centrifugation. Nature, Lond. 202 , 292-293.

De Gier, J., Mandersloot, J.G. \& Van Deenen, L.L.M. (1968) Lipid composition and permeability of liposomes. Biochim. Biophys. Acta 150, 666-675.

Evans, R.W. \& Setchell, B.P. (1978a) Association of exogenous phospholipids with spermatozoa. $J$. Reprod. Fert. 53, 357-362.

Evans, R.W. \& Setchell, B.P. (1978b) The effect of rete testis fluid on the metabolism of testicular spermatozoa. J. Reprod. Fert. 52, 15-20.

Evans, R.W. \& Setchell, B.P. (1979) Lipid changes during epididymal maturation in ram spermatozoa collected at different times of the year. J. Reprod. Fert. 57, 197-203.

Fraenkel, G. \& Hopf, H.J. (1940) The physiological action of abnormally high temperatures on poikilothermic animals. 1. Temperature adaptation and the degree of saturation of the phosphatides. Biochem. $J$. 34, 1085-1092.

Gresson, R.A.R. \& Zlotnik, I. (1945) A comparative study of the cytoplasmic components of the male germ cells of certain animals. Proc. Roy. Soc. Edinb. $B$ 62, 137-161.

Grogan, D.E., Mayer, D.T. \& Sikes, J.D. (1966) Quantitative differences in phospholipids of ejaculated spermatozoa and spermatozoa from three levels of the epididymis of the boar. J. Reprod. Fert. 12, $431-436$.

Hartree, E.F. (1972) Determination of protein: a modification of the Lowry method that gives a linear photometric response. Analyt. Biochem. 48, 422-427.

Hinton, B.T., Setchell, B.P. \& White, R.W. (1977) The determination of myo-inositol in micropuncture samples from the testis and epididymis of the rat. $J$. Physiol., Lond. 265, 14P-15P. 
Howell, R.W. \& Collins, F.I. (1957) Factors affecting linolenic and linoleic acid content of soybean oil. Agron. J. 49, 593-597.

Johnson, L.A., Gerrits, R.J. \& Young, E.P. (1969) Quantitative analysis of porcine spermatozoa and seminal plasma phospholipids as affected by frequency of ejaculation. J. Reprod. Fert. 19, 95102.

Johnson, L.A., Pursel, V.G. \& Gerrits, R.J. (1972) Total phospholipid and phospholipid fatty acids of ejaculated and epididymal semen and seminal vesicle fluid of boars. J. Anim. Sci. 35, 398-403.

Jurtschuk, P., Sekuzu, I. \& Green, D.E. (1961) The interaction of the $\mathrm{D}(-) \beta$-hydroxybutyric apoenzyme with lecithin. Biochem. Biophys. Res. Commun. 6, 76-80.

Lewis, R.W. (1962) Temperature and pressure effects on the fatty acids of some marine ectotherms. Comp. Biochem. Physiol. 6, 75-89.

Marr, A.G. \& Ingraham, J.L. (1962) Effect of temperature on the composition of fatty acids in Escherichia coli. J. Bacteriol. 84, 1260-1267.

Moore, J.L., Richardson, T. \& DeLuca, H.F. (1969) Essential fatty acids and ionic permeability of lecithin membranes. Chem. Phys. Lipids 3, 39-58.

Neill, A.R. \& Masters, C.J. (1972) Metabolism of fatty acids by bovine spermatozoa. Biochem. J. 127, 375385.

Orgebin-Crist, M.C., Danzo, B.J. \& Davies, J. (1975) Endocrine control of the development and maintenance of sperm fertilizing ability in the epididymis. In Handbook of Physiology, Section 7, Vol. V, pp. 319338. Eds D. W. Hamilton \& R. O. Greep. Am. Physiol. Soc., Washington, D.C.

Overath, P., Schairer, H.V. \& Stoffel, W. (1970) Correlation of "in vivo" and "in vitro" phase transitions of membrane lipids in Escherichia coli. Proc. natn. Acad. Sci. U.S.A. 67, 606-612.

Pearson, L.H. \& Raper, H.S. (1927) The influence of temperature on the nature of the fat formed by living organisms. Biochem. J. 21, 875-879.

Poulos, A., Voglmayr, J.K. \& White, I.G. (1973a)
Phospholipid changes in spermatozoa during passage through the genital tract of the bull. Biochim. Biophys. Acta 306, 194-202.

Poulos, A., Darin-Bennett, A. \& White, I.G. (1973b) The phospholipid bound fatty acids and aldehydes of mammalian spermatozoa. Comp. Biochem. Physiol. 46B, 541-549.

Poulos, A., Brown-Woodman, P.D.C., White, I.G. \& Cox, R.I. (1975) Changes in phospholipids of ram spermatozoa during migration through the epididymis and possible origin of prostaglandin $F_{2 \alpha}$ in testicular and epididymal fluid. Biochim. Biophys. Acta 388, 12-18.

Pursel, V.G. \& Graham, E.F. (1967) Phospholipids of bovine spermatozoa and seminal plasma. J. Reprod. Fert. 14, 203-211.

Quinn, P.J. \& White, I.G. (1967) Phospholipid and cholesterol content of epididymal and ejaculated ram spermatozoa and seminal plasma in relation to cold shock. A ust. J. biol. Sci. 20, 1205-1215.

Schlenk, H. \& Gellerman, J.L. (1960) Esterification of fatty acids with diazomethane on a small scale. Analyt. Chem. 32, 1412-1414.

Scott, T.W., Voglmayr, J.K. \& Setchell, B.P. (1967) Lipid composition and metabolism in testicular and ejaculated ram spermatozoa. Biochem. J. 102, 456461.

Setchell, B.P. (1978) The Mammalian Testis. Elek Books, London.

Suominen, J. \& Setchell, B.P. (1972) Enzymes and trypsin inhibitor in rete testis fluid of rams and boars. J. Reprod. Fert. 30, 235-245.

Trewhella, M.A. \& Collins, F.D. (1969) The relative turnover of individual molecular species of phospholipids. Lipids 4, 304-307.

Voglmayr, J.K., Scott, T.W., Setchell, B.P. \& Waites, G.M.H. (1967) Metabolism of testicular spermatozoa and characteristics of testicular fluid collected from conscious rams. J. Reprod. Fert. 14, 87-99.

Wilde, P.F. \& Dawson, R.M.C. (1966) The biohydrogenation of $\alpha$-linolenic acid and oleic acid by rumen micro-organisms. Biochem. J. 98, 469-475. 